\title{
DEVELOPMENT, STABILITY AND SENSORY ACCEPTIBILITY OF CUCUMBER-BASIL J UICE BLEND
}

M ajumdar $\mathrm{TK}^{1 *}$, Wadikar $\mathrm{DD}^{1}$ and $\mathrm{AS} B$ awa ${ }^{1}$

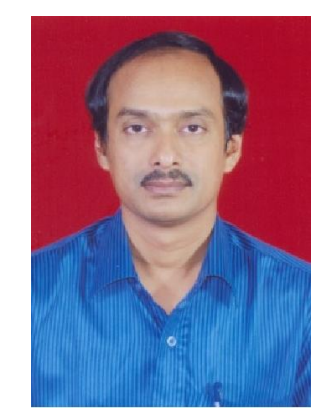

Tapas $\mathrm{M}$ ajumdar

*Corresponding author email: drdomysore@gmail.com

${ }^{1}$ Defence Food Research Laboratory, Defence Research \& Development Organisation, T.N.Pura Road, Mysore, India- 570011 


\section{ABSTRACT}

A blend of juices from Cucumber (Cucumis sativus) and Basil (O cimum sanctum) leaves was formulated with the help of Response Surface Methodology (RSM) and its storage stability was evaluated. Large quantities of Cucumber get spoiled in India during harvesting season. Long term preservation method of Cucumber juice is useful to prevent the spoilage of Cucumber. Addition of Basil juice increases the nutrient value of the juice blend as well as provides health benefit to the consumer. However, excess quantities of Basil juice in the product lead to unacceptable sensory qualities. Therefore, ingredients composition of the juice blend was optimized by Response Surface Methodology (RSM), a statistical design tool in which a central composite rotatable design has been used. The responses were analyzed to fit a polynomial model by least square technique. Amount of Lemon juice, Basil leaves juice and Cucumber juice, were independent variables and the overall sensory scores and acidity of the product were selected as the response. Generally the coding is done for the uniformity within the design and to avoid the bias. The coding is from -1 to +1 through ' 0 ' for minimum, maximum and the centre point, respectively. The actual experimental ranges of the levels of the major ingredients (independent variables) used in RSM varied from 50 to 75,25 to 50 and 5 to $10 \mathrm{ml}$ for Cucumber, Basil leaves and Lemon juices, respectively. The acidity response ranged between $0.2 \%$ and $0.42 \%$, whereas the sensory score response ranged between 6.0 and 7.9 in the experimental design. The optimized juice blend was filled in sterilized $200 \mathrm{ml}$ opaque white glass bottles. After filling, bottles were sealed with air tight cap and were pasteurized in hot water at $95^{\circ} \mathrm{C}$ for 15 minutes, and cooled.The physico-chemical, microbiological stability and sensory characteristics of the Cucumber-Basil juice thermally processed in glass bottle were evaluated during 6 months at room temperature $\left(28^{\circ} \mathrm{C} \pm 2^{\circ} \mathrm{C}\right)$. It was observed that mean $\mathrm{pH}$ values ranged from 3.89 to 4.00 during storage and the mean values of total acidity ranged from 0.25 to $0.36 \mathrm{~g}$ /100ml. Minor changes of total soluble solids ( $\left.{ }^{\circ} \mathrm{Brix}\right)$ values was observed during storage.Loss of vitamin $\mathrm{C}$ and $\beta$-carotene were $74.9 \%$ and $56.9 \%$ respectively after 6 months of storage. The result revealed that the optimized Cucumber-Basil juice is acceptable and can be preserved for 6 months with good acceptability.

K ey words: Cucumber, Basil, $\beta$-carotene, Vitamin C, Sensory 


\section{INTRODUCTION}

Cucumber-Basil juice is a good source of minerals and vitamins .This ready-to-drink, thirst quenching blended juice will satisfy the consumer demand for nutritious, health food. Basil leaves are good source of $\beta$-carotene $(2500 \mu \mathrm{g} / 100 \mathrm{~g})$, and ascorbic acid $(67 \mathrm{mg} / 100 \mathrm{~g})$ [1, 2]. Basil (0 cimum sanctum) is a branched softly pubescent undershrub, 30 to $60 \mathrm{~cm}$ high plant belongs to Lamiaceae family which is digestive, diuretic, expectorant, stomachic, and useful in asthma, bronchitis, catarrhal fever, hiccough, vomiting, ringworm and skin diseases [3].Cucumber contains Calcium (20 $\mathrm{mg} / 100 \mathrm{~g})$, Iron $(0.7 \mathrm{mg} / 100 \mathrm{~g})$, thiamin $(0.3 \mathrm{mg} / 100 \mathrm{~g})$, niacin $(0.2 \mathrm{mg} / 100 \mathrm{~g})$, and riboflavin $(0.01 \mathrm{mg} / 100 \mathrm{~g})$ [4]. Long term preservation method of Cucumber juice is useful to prevent spoilage of cucumber during harvesting season. Large quantities of Cucumber get spoiled due to excess production. The Cucumber juice was blended with Basil leaves juice to provide more nutrients in the product as well as to provide health benefits to consumer. However, suitable quantities of Basil leaves juice are required to add to the Cucumber juice to develop a juice blend having good sensory qualities. Ingredients composition of Cucumber-Basil juice was optimized by Response Surface Methodology (RSM) to achieve good sensory acceptability of the product. The blended juice in glass bottle was pasteurized in hot water at $95^{\circ} \mathrm{C}$ for 15 minutes to achieve long shelf life of the product. Response Surface Methodology and Central composite design of experiments are used in statistical optimization of products or processes. Several researchers have reported the usage in product ingredient optimization $[5,6,7,8,9]$. Optimization of ingredient composition with RSM is essential to obtain a product having good taste, flavour and colour. Cucumber-Basil juice is not available commercially and research has not been carried out on preservation of this blended juice. Research on preservation and storage studies were mostly confined to carrot, pumpkin, tomato, spinach and beetroot juice $[10,11,12,13,14]$.

In the present study, storage stability of the Cucumber-Basil leaves blended juice was developed by RSM and the physico-chemical, microbiological and sensory characteristics of the juice were evaluated after every 30 days during 6 months.

\section{MATERIALS AND METHODS}

\section{Raw materials}

Tender and fresh Basil leaves, Cucumber and matured Lemons (Citrus limon ) were purchased at the local market (Mysore, India).

\section{Processing and formulation of the u uice}

Cucumber was cleaned with water, deskinned, cut into pieces, blanched in boiling water for 2 minutes and the juice was extracted using mechanical juice extractor. Basil leaves were seperated from stalk, cleaned, cut into small pieces, blanched in boiling water containing magnesium oxide $(0.1 \%)$ and potassium metabisulphite $(0.1 \%)$ for 2 minutes and then the juice was extracted by mechanical juice extractor. Ingredients composition of the juices were optimized by RSM, a statistical design 
tools which uses a central composite rotatable design to fit a polynomial model by least square technique (Design expert 6.09, Statease Inc. Minneapolis, USA). With the help of response surface methodology it is possible to create a product using regression equations that describes interrelations between input parameters and product properties [15]. For the experimental design the number of points were obtained on the basis of the number of independent factors (variables) decided for a product. Product characteristics were taken as responses. In the present context, Cucumber juice, Basil leaves Juice and Lemon juice were selected as independent variables while the overall sensory scores and acidity of the product were the responses. Food grade sugar and salt were added to the juice to improve the taste and flavour. The final product was filled in sterilized $200 \mathrm{ml}$ opaque white glass bottle. After filling, bottles were sealed with air tight cap and were pasteurized in hot water at $95^{\circ} \mathrm{C}$ for 15 minutes, cooled.

The product was stored at room temperature $\left(28^{\circ} \mathrm{C} \pm 2^{\circ} \mathrm{C}\right)$ for 6 months for establishing its shelf life with periodic evaluations after every 30 days.

A nalytical evaluation: Total acidity was determined by titration with Sodium Hydroxide standard solution and expressed as citric acid. Total, non-reducing and reducing sugars were determined according to Lane and Eynon method. Vitamin $\mathrm{C}$ was determined by colorimetric method and $\beta$-carotene was determined by column chromatography method [16]. Total soluble solids were determined by refractometer ATAGO (0-32 ( ${ }^{\circ}$ Brix). pH values were measured by pH meter ( WTW 340i, Fisher Bioblock Scientific, France) [17]. Microbial analysis were carried out according to APHA [18]. All estimations were carried out in triplicate at 30 day interval and the mean values were reported.

Sensory A nalysis

Initially and periodically, samples were evaluated by a panel of 30 semi-trained members for colour, flavour, taste and overall acceptability of the juices. The tests were performed using 9-point hedonic scale, where 9 was "like extremely" and 1 was "dislike extremely".

\section{Statistical A nalysis}

The data obtained was analysed statistically for mean and standard deviation. The statistical software was SAS version 8.1 (SAS Institute Inc., Statistical Analysis System, Cary, NC).

\section{RESULTS}

The experimental design with different independent variables and the respective observed responses for juice blend products are given in Tables- 2. Perturbation graph (Fig.1) reveals that out of three independent factors, factor ' $C$ ' (Lemon juice) plays a major role in deciding the acidity of final product. As the level of Cucumber juice as well as Basil leaves juice increase, the acidity of juice blend decreased. The perturbation graph (Fig.2) for sensory score reveals that, all the three independent 


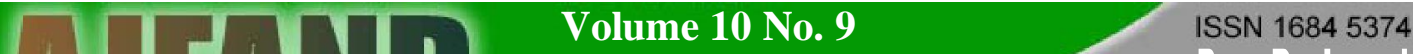 September 2010

variables affected it. However the higher levels of Cucumber juice improved the sensory score (Fig.3) of the juice blend.
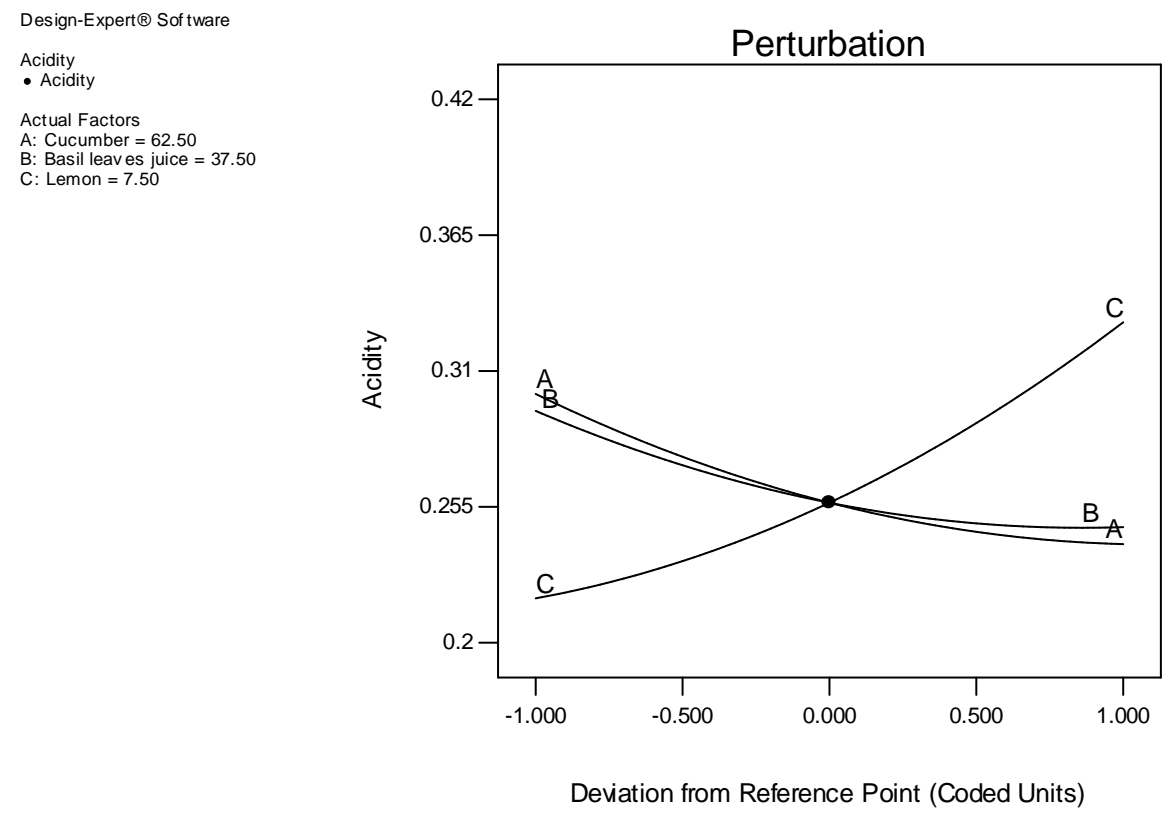

Figure 1: Perturbation graph showing the effect of independent variables on A cidity of the Cucumber-B asil juice blend

Design-Expert® Sof tware
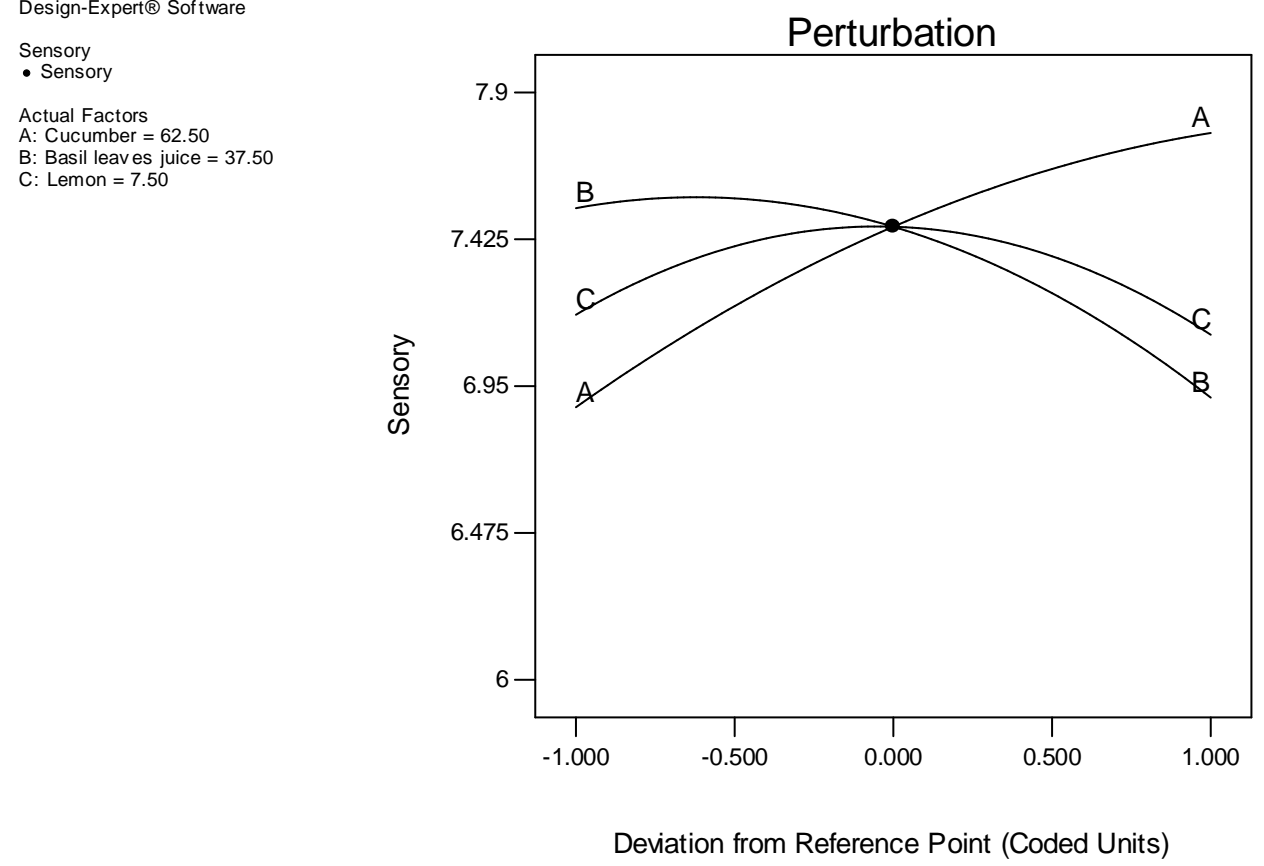

Figure 2: Perturbation graph showing the effect of independent variables on Sensory Score of Cucumber -Basil juice. 


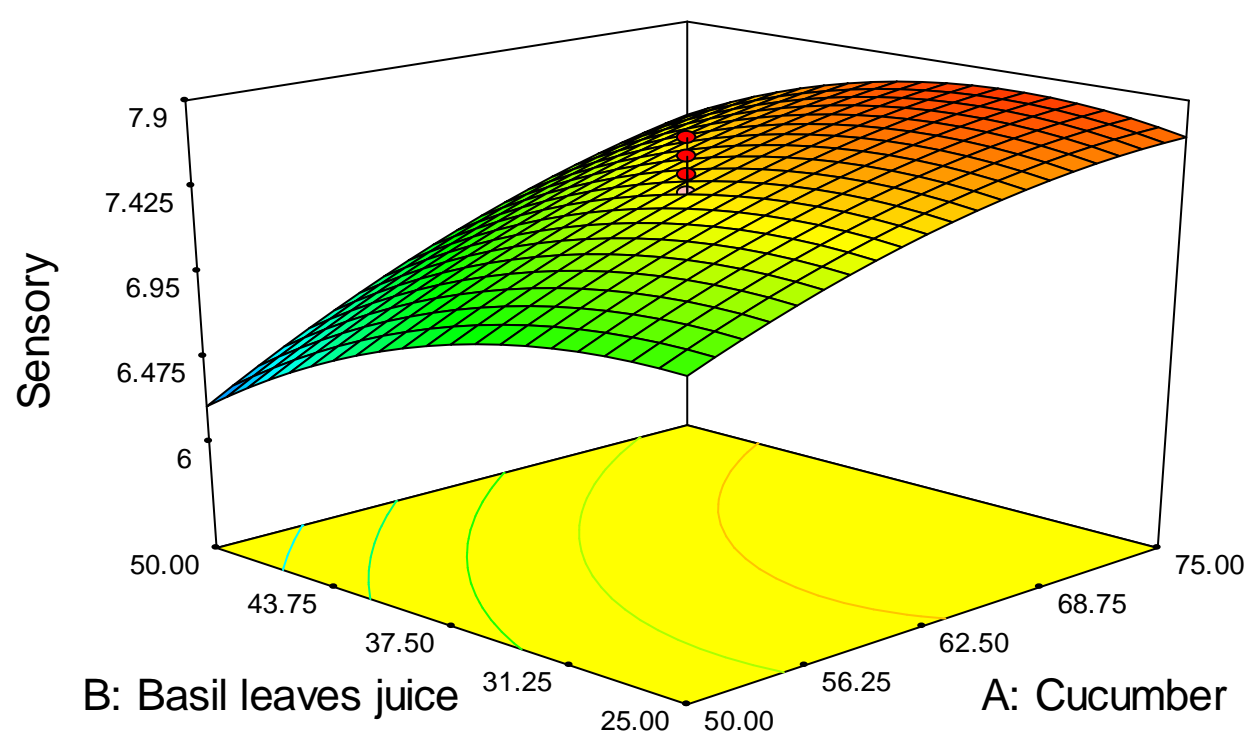

Figure 3: 3D plot depicting effect of Cucumber juice and Basil juice on Sensory score of the juice blend.

The analysis of variance was calculated for each selected model as well as response, to assess how well the model represented the data and performance statistics have been tabulated for both products (Table 3 ).

Multiple regression equations (in terms of coded factors) generated for the responses are as follows.

$$
\begin{aligned}
\text { Acidity }= & 0.26-0.03 \mathrm{~A}-0.024 \mathrm{~B}+0.056 \mathrm{C}-0.0012 \mathrm{~A} \mathrm{~B}-0.0087 \mathrm{~A} \mathrm{C}-0.011 \mathrm{~B} \mathrm{C} \\
& +0.014 \mathrm{~A}^{2}+0.014 \mathrm{~B}^{2}+0.017 \mathrm{C}^{2}
\end{aligned}
$$

Sensory $=+7.47+0.44$ A -0.31 B -0.032 C +0.13 A B +0.18 A C +0.18 BC $-0.14 \mathrm{~A}^{2}-$

$$
0.25 \mathrm{~B}^{2}-0.32 \mathrm{C}^{2}
$$

The desirable maximization of the polynomials thus fitted was performed by numerical techniques using the mathematical (numerical) optimization procedure of Design Expert ${ }^{\circledR}$ software package. The optimized levels of independent variables and the predicted response values are: Cucumber juice $=75.0 \mathrm{ml}(64.5 \%)$, Basil Leaves Juice $=33.5 \mathrm{ml}(28.8 \%)$, Lemon Juice $=7.8 \mathrm{ml}(6.7 \%)$, Acidity $=0.25 \mathrm{~g} / 100 \mathrm{~g}$, Sensory score $=7.8$. This optimized blend was processed and packed and was used for shelf life evaluation. 
The changes of $\mathrm{pH}$ values and total acidity was negligible during storage. It was observed that mean $\mathrm{pH}$ values ranged from 3.89 to 4.00 during storage ( Fig.4) and the mean values of total acidity ranged from 0.25 to $0.36 \mathrm{~g} / 100 \mathrm{ml}$ ( Fig.5). Minor changes of total soluble solids ( $\left.{ }^{\circ} \mathrm{Brix}\right)$ values was observed during storage.

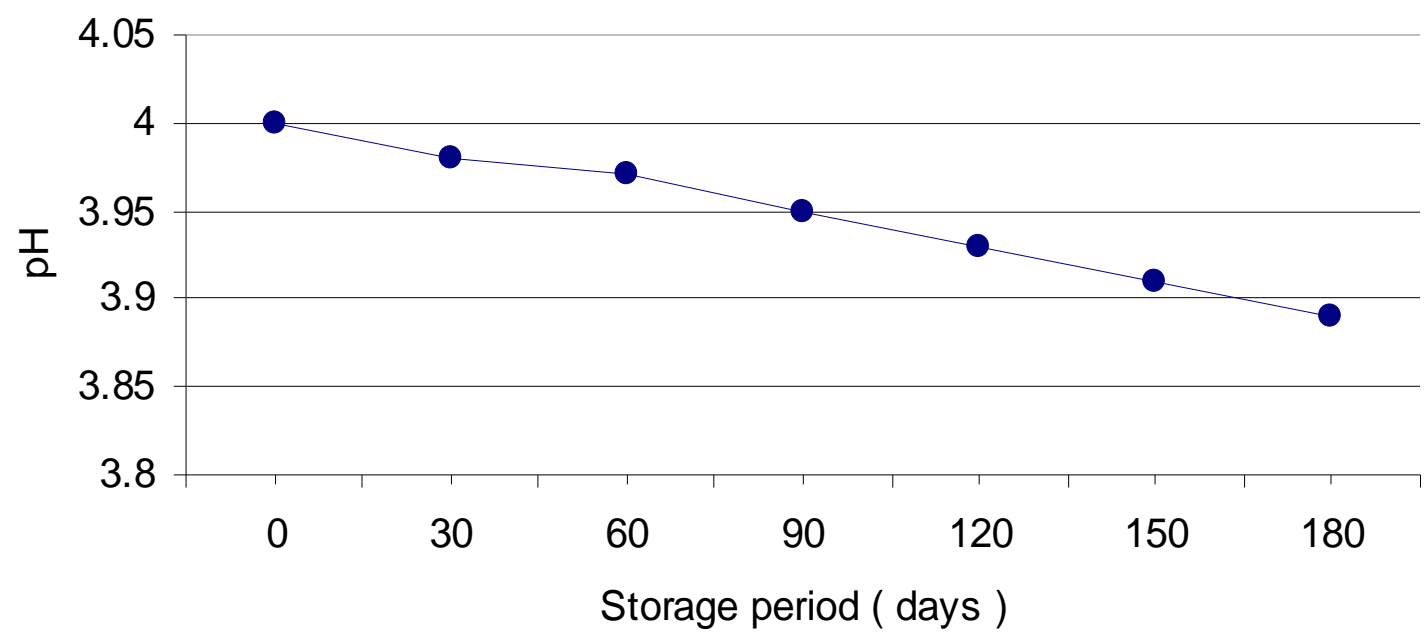

Figure 4: Changes of $\mathrm{pH}$ in Cucumber-Basil juice during storage. 


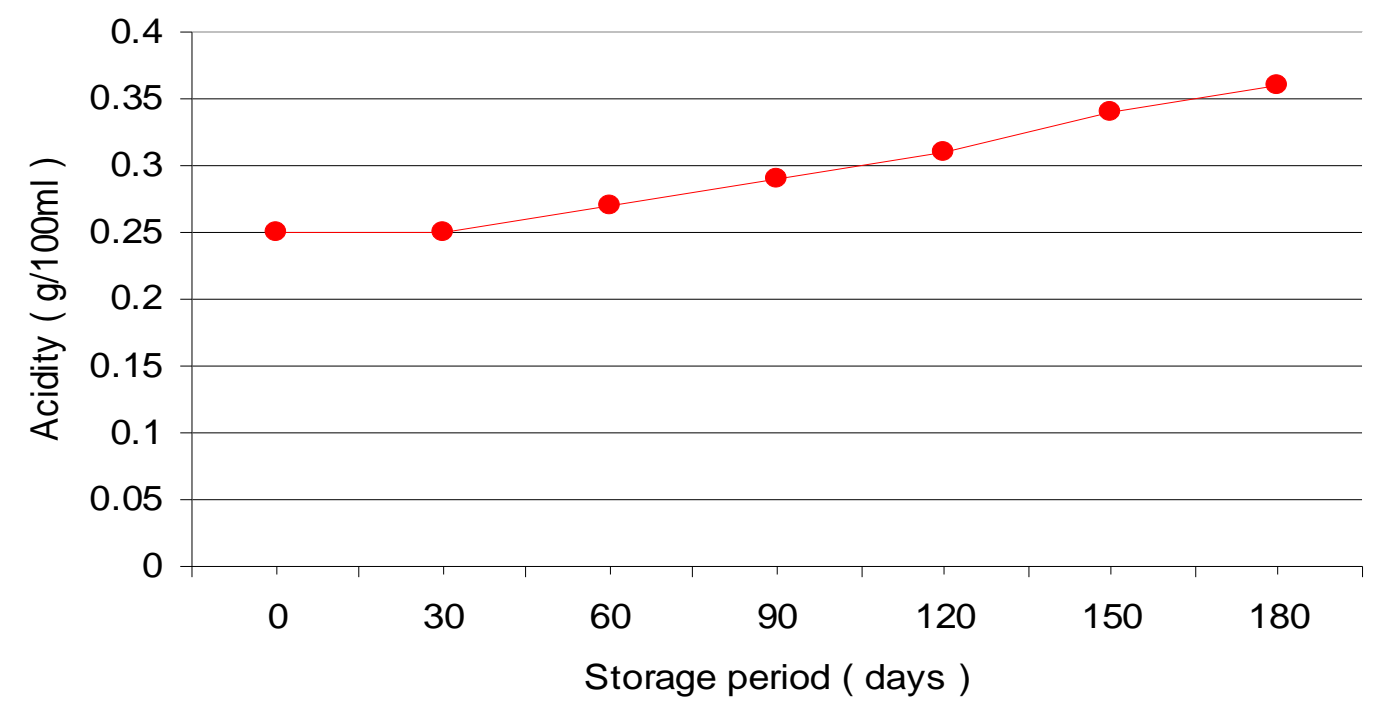

Figure 5: Changes of acidity in Cucumber-Basil during storage

Dhaliwal and Hira reported that pasteurization and storage of carrot-spinach and carrot-pineapple blended juice for 6 months showed small variations of $\mathrm{pH}$ values, total acidity, total solids and total sugars [19, 20].

Vitamin $C$ and $\beta$-Carotene values showed significant difference ( $\mathrm{P} \quad 0.05)$ during storage. V itamin C content decreased from $89 \mathrm{mg} / 100 \mathrm{ml}$ to $22.3 \mathrm{mg} / 100 \mathrm{ml}$ ( $74.9 \%$ loss,Fig.6) and $\beta$-Carotene content of the juice decreased from $2540 \mathrm{~g} / 100 \mathrm{ml}$ to $1093 \mathrm{~g} / 100 \mathrm{ml}$ during 6 months storage period (56.9\% loss, Fig.7). Losses of vitamin $C$ and $\beta$-Carotene during storage of tomato, amla, carrot, carrot-spinach, carrot-pineapple and carrot-beetroot juice have been reported by various authors and observed similar kind of losses [21, 22, 23, 24]. 


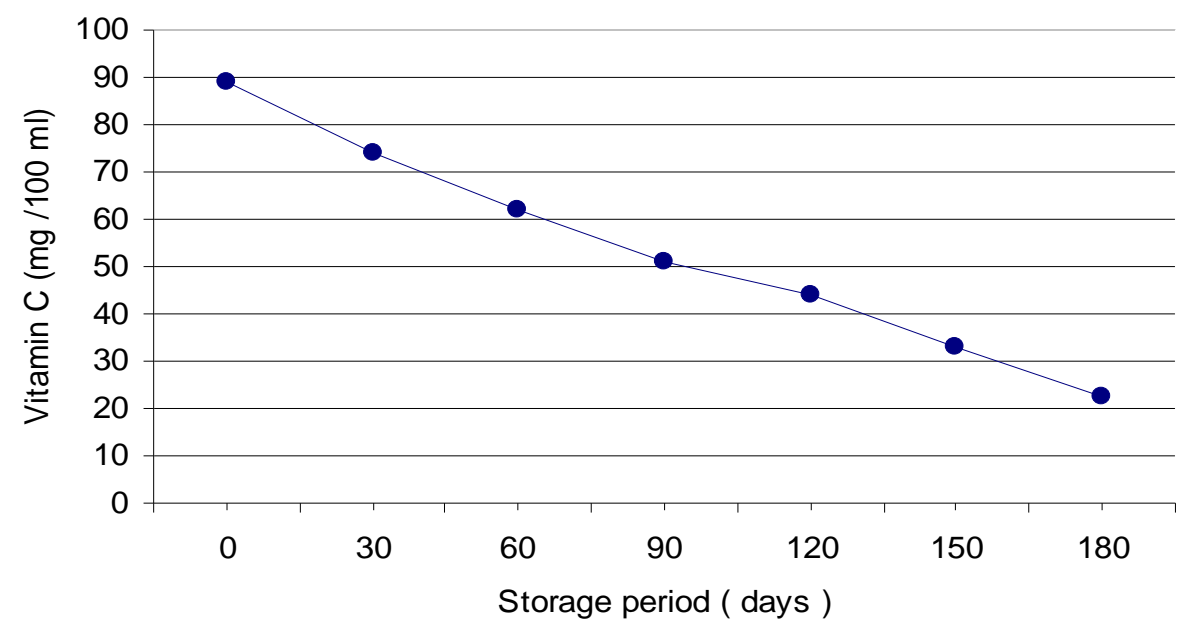

Figure 6: Stability of vitamin C in Cucumber-Basil juice during storage

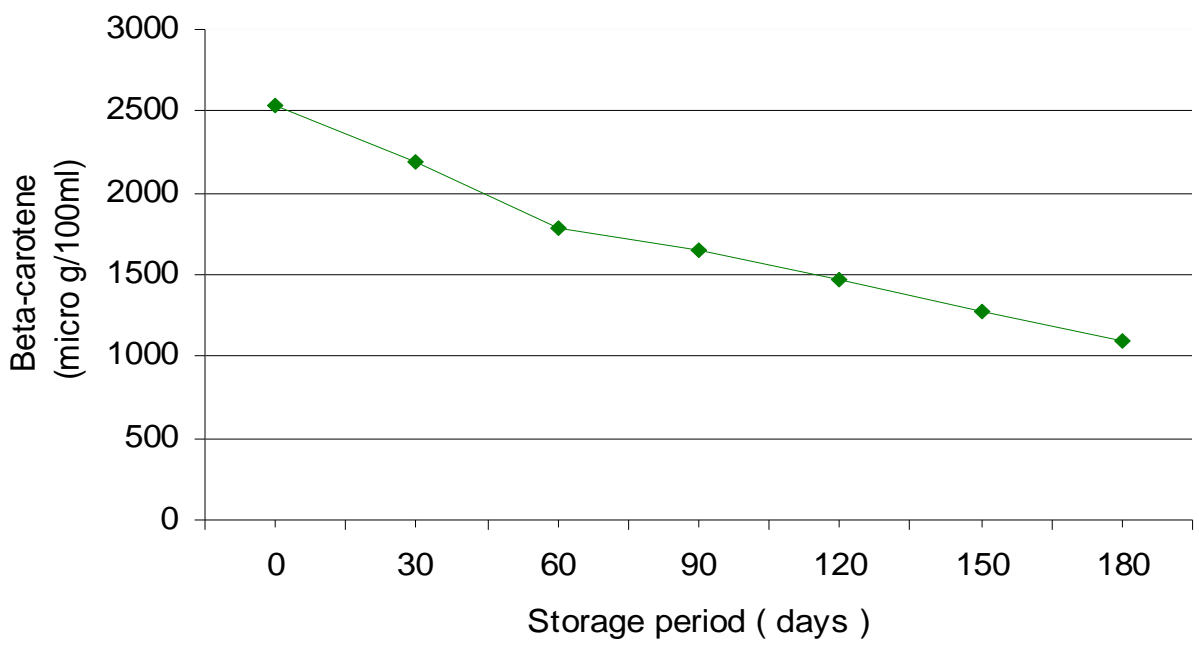

Figure 7: Stability of $\beta$-Carotene in Cucumber-Basil juice during storage 


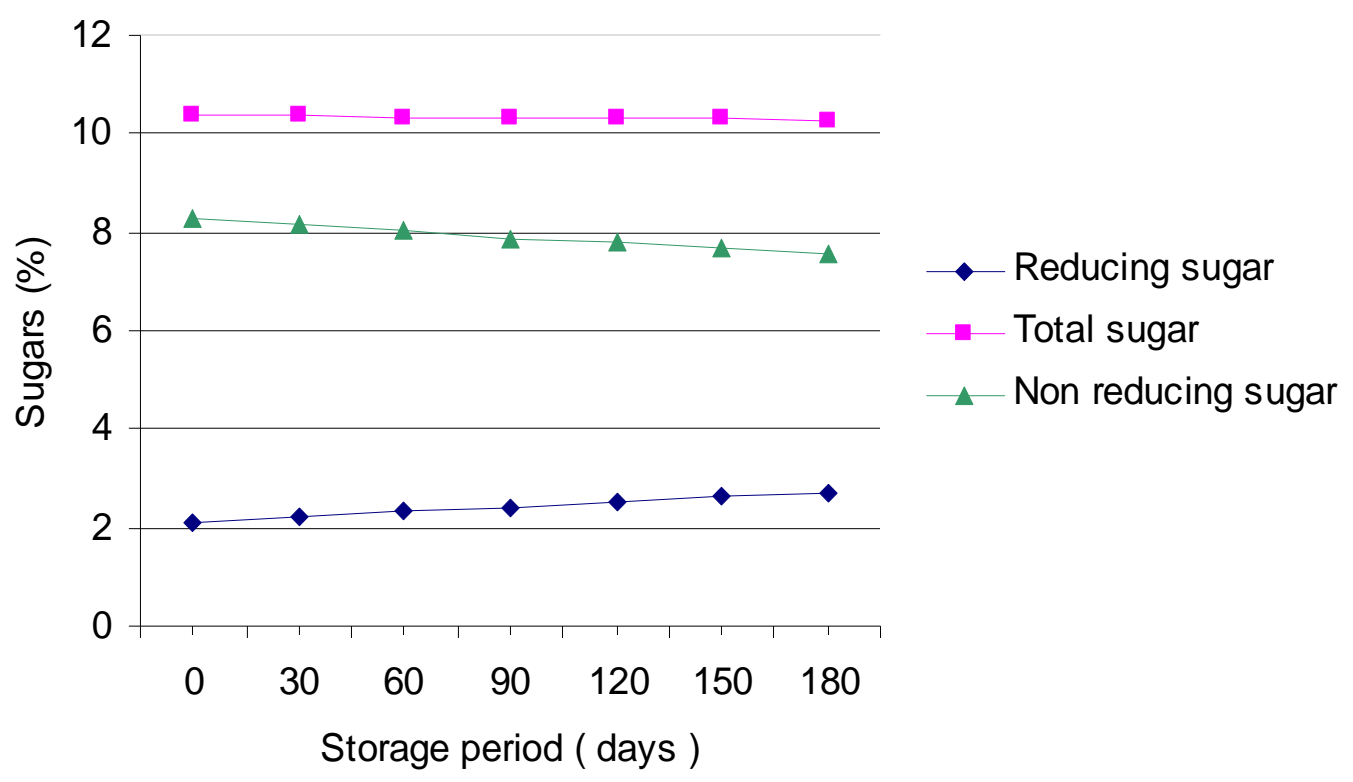

Figure 8: Stability of sugars in Cucumber-Basil leaves juice during storage.

A s shown in Fig.8, during the storage period, the reducing sugars increased while the non-reducing sugars decreased. There were negligible changes of total sugar during storage.

The Cucumber-Basil leaves juice was evaluated for its microbiological quality. Coliform, Spores, Y east and Mold counts were nil upto 6 months of storage. Total Plate Count (TPC) was nil upto 5 months of storage. However TPC was $10 \mathrm{cfu} / \mathrm{ml}$ after 6 months of storage.These results indicate that the microbiological quality of the product was satisfactory.

Sensory scores revealed that no remarkable difference was found for the colour, taste, flavour and overall acceptability of the product during the storage period. Mean values ranged from 7.0 to $8.0,7.1$ to $8.1,7.0$ to 8.0 and 7.0 to 8.1 for colour, taste, flavour and overall acceptability respectively indicating good acceptability of the product (Table 4 ).

\section{DISCUSSION}

Response Surface Methodology and Central composite design of experiments are used in statistical optimization of the ingredients composition of the juice. The results for the central composite designs were used to fit second order polynomial equation. The response surface plots of these models can be plotted as a function of two variables where the effect of all the variations in levels of independent factors in the designs, on different responses can be visualized for each response. The optimization 
criterion was to maximize the sensory score. The sensory score was affected considerably by changes in the level of all the three variables.

There was no fermentation of the juice during storage which was reflected in negligible change of acidity and $\mathrm{pH}$, microbiological safety and sensory scores of the product. Since the product was kept at ambient temperature $\left(28^{\circ} \mathrm{C} \pm 2^{\circ} \mathrm{C}\right)$ for long period, the loss of vitamin $C$ and $\beta$-carotene was high due to heat penetration in the juice for longer period and a lot of available oxygen ( $\mathrm{V}$ itamin $\mathrm{C}$ is oxygen scavenger). Reducing sugar increased during storage because of sucrose inversion in the presence of acidic environment. Inspite of loss of vitamin $C$ and $\beta$-carotene, increase of reducing sugar, negligible change of acidity and little change of sensory scores, the juice was acceptable upto 6 months of storage.

\section{CONCLUSION}

The physico-chemical changes of the juice had no remarkable effect on the sensory characteristics and acceptance of the Cucumber-Basil leaves blended juice during storage. Loss of vitamin $C$ and $\beta$-carotene were $74.9 \%$ and $56.9 \%$ respectively after 6 months of storage. The product was microbiologically safe during 6 months of storage.

It was concluded that Cucumber-Basil leaves blended juice can be effectively stored for a period of 6 months with good acceptability. 
Table 1: Experimental ranges and levels of independent variables used in RSM in terms of actual and coded factors for Cucumber -Basil leaves J uice

\begin{tabular}{|c|c|c|c|c|c|c|c|}
\hline \multirow{2}{*}{\multicolumn{2}{|c|}{ V ariables (g) }} & \multicolumn{6}{|c|}{ Range of Levels } \\
\hline & & \multirow{2}{*}{$\begin{array}{c}\text { A ctual } \\
50.0\end{array}$} & \multirow{2}{*}{$\begin{array}{c}\text { Coded } \\
-1\end{array}$} & \multirow{2}{*}{$\begin{array}{c}\text { Actual } \\
62.5\end{array}$} & \multirow{2}{*}{$\begin{array}{c}\text { Coded } \\
0\end{array}$} & \multirow{2}{*}{$\begin{array}{c}\text { Actual } \\
75.0\end{array}$} & \multirow{2}{*}{$\begin{array}{c}\text { Coded } \\
+1\end{array}$} \\
\hline A & Cucumber Juice & & & & & & \\
\hline B & Basil leaves juice & 25.0 & -1 & 37.5 & 0 & 50.0 & +1 \\
\hline C & Lemon juice & 5.0 & -1 & 7.5 & 0 & 10.0 & +1 \\
\hline
\end{tabular}

Table 2: Design of Experiments of Cucumber-Basil J uice

\begin{tabular}{|c|c|c|c|c|c|}
\hline Run & $\begin{array}{l}\text { Cucumber juice } \\
\text { Sensory } \\
(\mathrm{ml})\end{array}$ & Basil juice & Lemon juice & A cidity & \\
\hline 1 & 62.50 & 37.50 & 7.50 & 0.26 & 7.3 \\
\hline 2 & 50.00 & 50.00 & 5.00 & 0.26 & 6 \\
\hline 3 & 62.50 & 37.50 & 3.30 & 0.2 & 6.8 \\
\hline 4 & 41.48 & 37.50 & 7.50 & 0.35 & 6.2 \\
\hline 5 & 75.00 & 25.00 & 10.00 & 0.35 & 7.3 \\
\hline 6 & 75.00 & 50.00 & 10.00 & 0.28 & 7.5 \\
\hline 7 & 83.52 & 37.50 & 7.50 & 0.24 & 7.9 \\
\hline 8 & 62.50 & 37.50 & 7.50 & 0.25 & 7.5 \\
\hline 9 & 50.00 & 25.00 & 10.00 & 0.42 & 6.5 \\
\hline 10 & 62.50 & 58.52 & 7.50 & 0.25 & 6.1 \\
\hline 11 & 62.50 & 37.50 & 7.50 & 0.24 & 7.7 \\
\hline 12 & 75.00 & 50.00 & 5.00 & 0.22 & 6.6 \\
\hline 13 & 62.50 & 37.50 & 7.50 & 0.26 & 7.3 \\
\hline 14 & 75.00 & 25.00 & 5.00 & 0.24 & 7.3 \\
\hline 15 & 62.50 & 37.50 & 7.50 & 0.26 & 7.6 \\
\hline 16 & 50.00 & 25.00 & 5.00 & 0.28 & 7 \\
\hline 17 & 50.00 & 50.00 & 10.00 & 0.36 & 6 \\
\hline 18 & 62.50 & 16.48 & 7.50 & 0.34 & 7.4 \\
\hline 19 & 62.50 & 37.50 & 7.50 & 0.27 & 7.4 \\
\hline 20 & 62.50 & 37.50 & 11.70 & 0.41 & 6.3 \\
\hline
\end{tabular}


Table 3: ANOVA and model statistics for the Cucumber-Basil juice

\begin{tabular}{lcc}
\hline \multirow{2}{*}{ Term } & \multicolumn{2}{c}{ Response } \\
\cline { 2 - 3 } Model & $\begin{array}{c}\text { Acidity } \\
\text { Quadratic }\end{array}$ & $\begin{array}{c}\text { Sensory Score } \\
\text { Quadratic }\end{array}$ \\
\hline F. Value & 73.28 & 19.68 \\
P $>$ F & 0.0001 & 0.0001 \\
Mean & 0.29 & 6.98 \\
S.D. & 0.011 & 0.20 \\
C.V. & 3.68 & 2.81 \\
R squared & 0.9849 & 0.9466
\end{tabular}




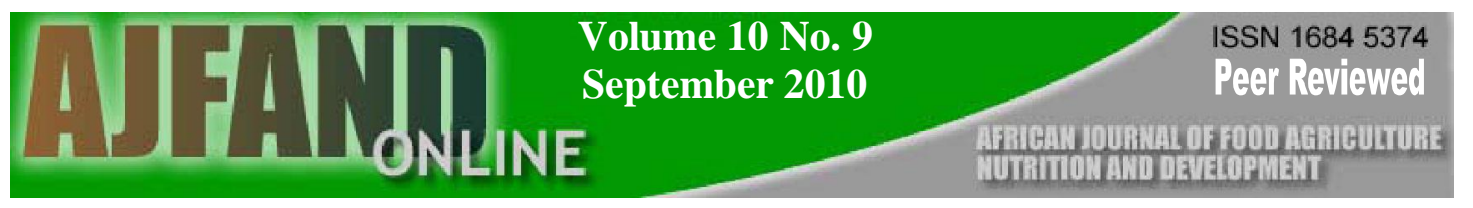

Table 4: Sensory scores of thermal processed Cucumber-Basil leaves J uice

\begin{tabular}{lccccccc}
\hline Months & 0 & 1 & 2 & 3 & 4 & 5 & 6 \\
\hline Colour & $8.0 \pm 0.16$ & $8.0 \pm 0.16$ & $8.0 \pm 0.21$ & $7.7 \pm 0.20$ & $7.5 \pm 0.11$ & $7.2 \pm 0.16$ & $7.0 \pm 0.22$ \\
A roma & $8.0 \pm 0.20$ & $8.0 \pm 0.20$ & $7.9 \pm 0.12$ & $7.6 \pm 0.12$ & $7.3 \pm 0.20$ & $7.2 \pm 0.20$ & $7.0 \pm 0.16$ \\
Taste & $8.1 \pm 0.25$ & $8.1 \pm 0.25$ & $8.0 \pm 0.20$ & $7.7 \pm 0.22$ & $7.3 \pm .18$ & $7.3 \pm 0.12$ & $7.1 \pm 0.12$ \\
$\begin{array}{l}\text { Overall } \\
\text { acceptability } \\
\text { score }\end{array}$ & $8.1 \pm 0.20$ & $8.1 \pm 0.20$ & $7.8 \pm 0.16$ & $7.5 \pm 0.13$ & $7.3 \pm 0.25$ & $7.1 \pm 0.21$ & $7.0 \pm .26$ \\
\hline
\end{tabular}




\section{REFERENCES}

1. Chen $B H, C$ huang J $R$, Lin J H and $C P$ Chin Quantification of provitamin $A$ compounds in chinese vegetables by high performance liquid chromatography. J . Food Protect. 1993; 56(10): 51-54.

2. Yamawaki $\mathrm{K}, \mathrm{M}$ orita $\mathrm{N}, \mathrm{M}$ urakamik $\mathrm{K}$ and $\mathrm{T} \mathrm{M}$ urata Content of ascorbic acid and ascorbate oxidase activity in fresh herbs. J. J apanese Soci. F ood Sci. Technol. 1993; 40(9): 636-640.

3. Prajapati ND, Purohit SS, Sharma AK and T Kumar A Handbook of Medicinal plants, 1st Edition, Agrobios (India), Jodhpur, India, 2003: 367.

4. Bose TK Fruits of India,T ropical and Sub Tropical. $1^{\text {st }}$ edition, Naya Prokash Publication, Kolkata, India 1985.

5. Raghavan CV, Srichandan BR, Nagin C and PN Rao Response surface analysis of power consumption of dough sheeting as a function of gap, reduction ratio, water, salt and fat. J F ood Sci. Technol. 1996; 33: 313-321.

6. Rathi P, Goswami VK, Sahai V and R Gupta Statistical medium optimization and production of a hyperthermostable lipase from Burkholderia cepacia in a bioreactor. J Applied M icrobiol. 2002; 93: 930-936.

7. Gill BS, Sodhi NS, Narpinder S, Maninder S and S Davinder Effects of ${ }^{\circ}$ brix, sodium alginate and drying temperature on color, texture and sensory properties of Dushehari mango leather.J Food Sci. Technol.2004; 41:373 278.

8. Ismail YS, Rustom MH, Lopez-levia and BM Nair Optimization of extraction of peanut proteins with water by Response Surface Methodology. J Food Sci. 1991; 56: 1660-1663.

9. Wadikar DD, M ajumdar TK, Nanjappa C, Premavalli K S and AS Bawa Development of shelf stable pepper based appetizers by Response Surface Methodology (RSM). LWT-F ood Sci. \& Technol. 2008; 41(8):1400-1411.

10. Ayranci $G$ and A Tuetuencueler Preparation and storage stability of juices from different carrot species. Nahrung 1993; 37(5): 433-439.

11. H $\sin Y W$ and WJ Swi-Bea PH adjustment and high temperature sterilization of spinach juice. Food sci.Taiwan 1996; 23(5): 662-670.

12. Chen $H E$, Peng $H Y$ and $B H$ Chen Stability of carotenoids and vitamin $A$ during storage of carrot juice. Food Chemi.1996; 57(4): 497-503. 
13. Bong $\mathrm{YO}$ and $\mathrm{H}$ Bock Changes in physico-chemical components of stwed pumpkin juice with ingredients during storage. J Korean Soci. food sci.Nutri. 1998; 27(6): 1027-1033.

14. Su-Y eun $K, Y$ oung-Bean $Y$ and $C$ Eon-Ho Change in quality of mixed juice of fruits and vegetables by aseptic treatment and packing with nitrogen gas during storage. Korean J.Food Sci.T echnol. 2000; 32(6): 1271-1277.

15. Colona P, Doublier J L, Melicion J P, Monfredon FD and C Mercier Extrusion cooking and drum drying of wheat starch. I. Physical and macromolecular modifications. Cereal Chemi. 1984; 61:538-543.

16. Ranganna S Handbook of Analysis and Quality control for Fruits and V egetable products, $2^{\text {nd }}$ ed. pp881-882,885 T ata MCgRAW- Hill Publication, New Delhi.1986.

17. AOAC. Official Methods of Analysis. A ssociation of Official A nalytical Chemists, Washington DC.1990.

18. APHA. Compendium of Methods for the Microbiological Examination of Foods,A merican Public Health A ssociation, W ashington DC, 2001.

19. Dhaliwal $\mathrm{M}$ and $\mathrm{CK}$ Hira Effect of storage on physico-chemical and nutritional characterstics of Carrot-Spinach and Carrot-Pineapple juices. J F ood Sci. Technol. 2004; 41: 613-617.

20. Dhaliwal $\mathrm{M}$ and $\mathrm{CK}$ Hira Effect of storage on physico-chemical and nutritional characterstics of Carrot-beetroot and Carrot-blackcarrot juices. J Food Sci. Technol.2001; 38: 343-347.

21. Aggarwal $P$, Singh B and J S Sidhu Studies on the physico-chemical and processing characterstics of some newly evolved cultivars for making juice and concentrate.I ndian F ood Pack. 1995; 49:45-53.

22. Dietz J M and W A G ould Effect of process stage and storage on retention of $\beta$-carotene in tomato juice. J F ood Sci. 1986; 51: 847-848.

23. K wasneiwska I, Nadolna I and G Lisowska Changes in the colour and vitamin $\mathrm{C}$ content of black carrot juices concentrate during manufacture and storage.P rzemysl F erment O woco 1987; 31: 19-22.

24. Nagra AS and S K han V itamin A ( $\beta$-carotene) losses in Pakistani cooking. J Sci. Food Agric. 1988; 46: 249-251. 